\title{
SEMANTIESE MEERDUIDIGHEID IN MOTIVERINGSNAVORSING
}

\section{S.H. ZIETSMAN}

AFDELING ORGANISASIE EN WERKSTUDIE

EVKOM (WES-KAAPLANDSE STREEK)
I. VAN W. RAUBENHEIMBER ${ }^{*}$

DEPARTEMENT BEDRYFSIELKUNDE

UNIVERSITEIT STELLENBOSCH

\section{SUMMARY}

The premise is made that semantic ambiguity, which is manifested in measuring instruments, could lead to controversial and divergent research results often reported in studies on work motivation. Researchers, the literature indicates, are largely unaware of this phenomenon. In this investigation no studies were found in which semantic ambiguity in questionnaires had been controlled. In order to demonstrate the existence of semantic ambiguity as a phenomenon, a semantic differential was administered to 38 Industrial Psychology students in order to measure the meaning of the items on the Pottas Need Questionnaire. The results indicated that six of the 13 questionnaire items differed significantly from the need categories they purported to measure, which confirmed the notion that semantic ambiguity is a source of variance that should be controlled.

Organisasies bied ' $n$ belangrike en interessante arena waarbinne motivering bestudeer kan word. Die rede hiervoor is tweërlei van aard. Eerstens word 'n groot gedeelte van die individu se tyd in beslag geneem deur sy werk en gevolglik deur die organisasie. Om hom gelukkig te hou in sy werk is dit dus noodsaaklik dat die individu meer as bloot net finansieel vergoed word vir sy arbeidsmoeite.

Tweedens is motivering, uit die oogpunt van die werkgewer, noodsaaklik vir die doeltreffende en winsgewende voortbestaan van die organisasie. Dit blyk dus 'n logiese afleiding te wees dat die organisasie sy produktiwiteit kan verhoog deur 'n klimaat te skep wat tot verhoogde motivering van sy lede sal lei.

Alhoewel daar verskillende benaderings tot motivering is, elkeen met sy eie verklaring en gevolglik eie definisie, kan daar met 'n redelike mate van sekerheid gestel word dat motivering minstens die volgende insluit: (a) Kragte wat gedrag opwek, (b) dit in 'n sekere rigting stuur en (c) laat aanhou totdat 'n doel bereik is; wat die inisieerende kragte sodanig verminder dat dit nie meer gedrag beïnvloed nie.

\footnotetext{
* Tans by die Randse Afrikaanse Universiteit
} 
Volgens hierdie onskrywing is dit moontlik om drie fases in die motiveringsproses te onderskei:

Beginpunt - $\quad$ 'n Toestand (bv. behoeftes, motiewe, spanning, verwagtings, drange, begeertes) wat sekere dryfkragte in 'n individu opwek of laat ontstaan.

Beweging - Die bewustelike of onbewustelike aanwending van energie wat die individu weg laat beweeg vanaf die beginpunt, in die rigting van ' $n$ sekere doel.

Eindpunt - ' $\quad$ n Toestand van homeostase waar daar 'n balans is tussen al die kragte en invloede wat op die individu inwerk (satisfaksie) en waar die oorsaak van die beweging sodanig verdwyn dat dit nie meer 'n invloed op die individu uitoefen nie.

Die aard en omvang van die toestand wat die individu in die eerste fase ervaar (die beginpunt) bepaal die aard en omvang van die doelstelling waarna die individu streef en gevolglik die aard en omvang van die energie wat die individu gaan aanwend om hierdie doelstelling te bereik en sodoende die aanvanklike toestand genoegsaam te elimineer. Dit is dus verstaanbaar dat meeste motiveringsteorieë meesal op die eerste fase konsentreer, aangesien dit die beginpunt van die motiveringsiklus vorm.

' $n$ Duidelike begrip van die komplekse proses van motivering hang saam met die korrekte identifisering van die toestande wat motiveringskragte opwek. Vir hierdie doel moet die navorser hom dikwels beroep op die gebruik van vraelyste om die toestand waar te neem. Die korrektheid van die inligting wat die navorser sodoende inwin (en van sy gevolgtrekkings) berus op die vertroubaarheid van die meetinstrument wat hy gebruik. Dit behoort daarom die navorser se doel te wees om te streef na die ontwikkeling van ' $n$ vertroubare instrument dus ' $n$ geldige en betroubare instrument.

Navorsing (Nunnally, 1967; Osgood, Suci \& Tannenbaum, 1957) dui daarop dat betekenis as sodanig van ' $\mathrm{n}$ hoogs gekompliseerde aard is, met die gevolg dat veralgemenings omtrent die betekenisse wat individue aan onder andere vraelysitems heg, nie moontlik is nie. Teen hierdie agtergrond kan aangevoer word dat semantiese meerduidigheid (die uiteenlopendheid van betekenisse wat verskillende individue aan verskillende konsepte heg) in meetinstrumente, die navorser se resultate kan kontamineer.

Dit wil voorkom asof navorsers grootliks onbewus is van die kontaminerende invloed wat semantiese meerduidigheid op hul resultate kan hê. In 'n ondersoek, waarin gepoog is om 
kontroversiele en uiteenlopende navorsingsresultate rondom vier motiveringsteorieë (Billikheidsteorie, Verwagtingsteorie, en die teorieë van Maslow en Herzberg) in verband te bring met die verskynsel van semantiese meerduidigheid, is geen aanduidings gevind dat navorsers hul meetinstrumente vir die moontlike aanwesigheid van semantiese meerduidigheid ondersoek het nie (Zietsman, 1978). Die feit dat daar nêrens bewyse gevind is dat hierdie waarskynlike bron van variansie gekontroleer is nie) laat onwillekeurig die vraag ontstaan of semantiese meerduidigheid inderdaad nie aanleiding kon gee tot die kontroversies en uiteenlopendheid van soveel gerapporteerde navorsingsresultate in verband met motiveringsteorieë nie.

' $n$ Verdere uitvloeisel van die semantiese meerduidigheidsprobleem soos wat dit in motiveringsnavorsing figureer, is die probleem van nie-differensiasie tussen organisatoriese vlakke, sover dit die konstruksie van vraelyste aangaan. In talle studies wat deur Zietsman (1978) ondersoek is, is teorieë nagevors oor "n globale spektrum van werknemers op verskillende organisatoriese vlakke - vanaf lae organisatoriese vlakke tot topbestuursvlakke terwyl nie een van die vraelyste wat vir hierdie doel gebruik is, aangepas is vir die verskillende vlakke, of selfs ondersoek is om vas te stel of individue op die verskillende vlakke die vraelyste verstaan het nie.

Dit sal waarskynlik geen gewaagde stelling wees nie om aan te voer dat topbestuursamptenare met ' $n$ hoë opvoedingspeil, ander sosiale agtergrond, beter taalgebruik en - begrip, ander konnotasies sal heg aan dieselfde vraelysitems as werkers op die lae organisatoriese vlakke met 'n laer opvoedingspeil, ander sosiale agtergrond en verarmde taalgebruik en begrip nie. In hierdie verband beweer Porter (1963a, p. 147): "It is possible that when questions are asked about the importance of various needs and opportunities in the work situation, those with less formal education may have a stronger response set to consider 'everything' as quite important. On the other hand, those with more education may be more selective and restrained in using attitude scales and in responding to such questions."

Sover dit die bovermelde tipe navorsing aangaan, het veral die teorie van Maslow (Maslow, 1954) vergelykings tussen werknemers op verskillende organisatoriese vlakke, ten opsigte van belangrikheid van behoeftevervulling en graad van behoeftebevrediging, gestimuleer.

In die eerste van 'n wye reeks studies oor Maslow se behoefte hiërargie, het Porter (1961) waargenome gebrek aan behoeftebevrediging vir werknemers op twee organisatoriese vlakke (lae vlak en middelvlak) ondersoek. Hy bevind beduidende verskille tussen hierdie 
twee vlakke in drie behoeftekategorieë naamlik erkenning $(\mathrm{p}<, 005)$; sekuriteit $(\mathrm{p}<, 06)$ en selfstandigheid $(\mathrm{p}<, 02)$. Laasgenoemde behoeftes was beduidend meer bevredig vir werknemers op die middelvlak as vir werknemers op die lae vlak. Steun word aan hierdie resultate verleen in ' $\mathrm{n}$ latere studie van Porter (1962), waarin hy waargenome gebrek aan behoeftebevrediging op vyf bestuursvlakke (president; visepresident; hoër middel, laer middel, en laer) ondersoek het. Dit toon dieselfde tendens op die twee laagste vlakke en dui boonop aan dat hierdie tendens volhou tot op die hoogste vlak. Gebrek aan behoeftebevrediging neem progressief af vanaf die laer bestuursvlakke na die hoër bestuursvlakke vir drie van die vyf behoefte-kategorieë (erkenning, selfstandigheid en selfverwesenliking) .

Studies deur Rhinehart, Barrell, de Wolfe, Griffin en Spaner (1969) en Pottas (1969) verleen steun aan die bevindings van Porter. Resultate van 'n studie deur Mitchell (1970) stem deels ooreen met die Porterbevinding, maar bevat twee gevalle wat lynreg daarmee verskil, terwyl Ivancevich (1969) geen beduidende tendense berig nie.

Rhinehart, et al. (1969) bevind ' $n$ tendens van afname in gebrek aan behoeftebevrediging vanaf lae vlak werknemers na hoë vlak werknemers op vier organisatoriese vlakke. Die verskil tussen elke vlak is beduidend $(\mathrm{p}<, 01)$. Ook dui die resultate van 'n studie deur Pottas (a.w.) daarop dat werknemers op laer bestuursvlakke minder bevrediging van hoërorde behoeftes ervaar as werknemers op hoër bestuursvlakke en dat selfverwesenliking en selfstandigheid deur werknemers op die laer en hoër vlakke as die behoefte-areas beskou word waarin die grootste gebrek aan bevrediging voorkom.

Die bevindings van die Porterstudies (Porter, 1961, 1962) word egter nie onderskryf vir alle groepe in 'n studie deur Mitchell (1970) nie. In twee van ses groepe wat bestudeer is, rapporteer leeroffisiere in hoër range meer gebrek aan behoeftebevrediging vir die behoeftekategorieë van erkenning, selfstandigheid en selfverwesenliking as offisiere in die laer range.

Alhoewel Invancevich (1969) in 'n ondersoek op twee vlakke (hoofbestuurders en middelbestuurders) vind dat die behoefte aan selfverwesenliking en selfstandigheid vir beide vlakke, die grootste gebrek aan bevrediging inhou, vind hy in teenstelling met Porter (1961, 1962) se resultate, dat gebrek aan behoeftebevrediging nie afneem vanaf middelbestuurders na hoof-bestuurders nie. 'n Moontlike rede vir hierdie verskynsel is die feit dat beide vlakke senior posisies insluit. Hoofbestuurders sluit presidente en vise-presidente in, terwyl middelbestuur saamgestel is uit afdelings-, eenheids- en senior departementele bestuurders. 
Uiteenlopende resultate word ook berig in gevalle waar navorsers die vraag ondersoek het of daar sistematiese veranderings plaasvind in die belangrikheid wat proefpersone aan behoeftevervulling heg vanaf laer na hoër organisatoriese vlakke, soos wat dit die geval is met waargenome gebrek aan behoeftebevrediging.

Porter (1961) vind geen beduidende verskille tussen lae vlak en middelvlak werknemers ten opsigte van die belangrikheid wat hulle aan die vyf behoeftekategorieë heg nie. Die resultate reflekteer egter ' $\mathrm{n}$ tendens by die lae vlak werknemers om 'n effens hoër graad van belangrikheid te heg aan 13 van 15 vraelysitems vergeleke met die hoë vlak werknemers.

In teenstelling hiermee rapporteer Porter (1963a) 'n algemene tendens $(\mathrm{p}<, 01)$ vir hoë vlak bestuurders om groter belangrikheid aan behoeftes te heg as lae vlak bestuurders, veral ten opsigte van die hoërorde behoeftes, selfstandigheid en selfverwesenliking. Hierdie resultate word egter deur Pottas (1969) weerlê in 'n studie waar hy weinig aanduidings vind van die toenemende belangrikheid van hoërorde behoeftevervulling vir werknemers in hoër range, hoër beroepsvlakke en vir die beter gekwalifiseerdes, teenoor diegene in die laer range, laer beroepsvlakke en vir die minder gekwalifiseerdes.

Huizinga (1970) bevind dat individue op hoër vlak en laer vlak verskil i.t.v. die laerorde behoeftes. Geen verskille is waargeneem in terme van die belangrikheid wat beide groepe aan die hoërorde behoeftes heg nie. Vir die laerorde behoeftes verskil die twee groepe wel in soverre individue op die laer vlakke beduidend meer belangrikheid aan die laerorde behoeftes heg $(\mathrm{p}<, 001)$ as individue op die hoër vlakke.

Die vraelys van Porter geniet verbasend wye aanvaarding in die studies hierbo genoem asook in talle ander studies wat individue se behoeftesamestellings ondersoek (Rhinehart, et al., 1969; Invancevich, 1969; Pottas 1969, in Afrikaans vertaal; Porter, 1961, 1962, 1963a; Mitchell, 1970; om slegs enkeles te noem).

' $\mathrm{n}$ Beswaar teen die Portervraelys, en een wat die dryfveer agter hierdie ondersoek is, is 'n gebrek aan kontrole vir die verskynsel van semantiese meerduidigheid. Alhoewel Osgood, Suci en Tannenbaum (1957) duidelik aanvoer dat betekenis vele fasette het en dat verskillende individue verskillende betekenisse aan sekere begrippe of waarde heg, het Porter weinig navorsing gedoen om hierdie moontlike bron van variansie in sy vraelys te elimineer. Hierdie gebrek is ook te bespeur in die studies van latere navorsers wat die Portervraelys gebruik het, en veral in die geval van navorsers wat van vertaalde weergawes van die Portervraelys gebruik gemaak het (Porter \& Siegel, 1965; Slocum et al., 1971 en Pottas, 1969). 
Veral die werk van Pottas (1969) is van besondere belang, aangesien hy die teorie van Maslow in die Suid-Afrikaanse situasie ondersoek het deur middel van 'n letterlike Afrikaanse vertaling van die Portervraelys. 'n Aantal abstrakte begrippe word in hierdie vraelys aangetref en dit staan te betwyfel of die begrippe tot ' $n$ enkele eenheidsbetekenis by proefpersone sal lei, alvorens so aanname empiries bevestig is. Voorbeelde van sodanige begrippe is onder andere "prestige," "selfstandige denke en optrede," "persoonlike groei en ontwikkeling" en "selfvervulling".

Die vraag ontstaan gevolglik of individue in laer range, in laer beroepsvlakke en die minder gekwalifiseerdes, dieselfde betekenis aan hierdie begrippe sal heg as individue in hoër range, hoër beroepsvlakke en die beter gekwalifiseerdes.

Binne hierdie raamwerk kom twee ander aspekte van die vraelys ook in gedrang, naamlik die geldigheid en betroubaarheid van die vraelys. Wanneer ' $n$ instrument tot semantiese verwarring lei, kan dit nie geldig of betroubaar wees nie. Is semantiese meerduidigheid nie dalk 'n oorsaak van 'n tendens wat deur Porter (1963b) opgemerk is nie, naamlik dat dit wil voorkom asof daar geen verband bestaan tussen die gebrek wat proefpersone aan behoeftebevrediging ondervind en die belangrikheid van behoeftevervulling vir daardie proefpersone nie (soos gemeet deur sy vraelys), aangesien 'n behoeftekategorie waarin die grootste gebrek aan bevrediging ervaar is, nie noodwendig die belangrikste behoeftekategorie is nie?

Semantiese meerduidigheid is ' $n$ probleem wat tot dusver nog nie genoegsaam aandag ontvang het nie en 'n evaluering van talle navorsingstudies (Zietsman, 1978) bring aan die lig dat hierdie moontlike bron van variansie nie voldoende gekontroleer word nie. Die gebrek aan navorsing op hierdie gebied word treffend geïllustreer deur die verskynsel dat 'n vraelysitem("feeling of worthwhile accomplishment from my job") wat deur Dunnette, Campbell en Hakel (1967) gebruik word om prestasie te meet, in die Portervraelys onder die behoeftekategorie selfverwesenliking verskyn.

Die behoefte aan 'n ondersoek na semantiese meerduidigheid in motiveringsnavorsing bestaan waarskynlik al langer as wat tot dusver in die algemeen besef is. So byvoorbeeld vestig Lawler en Suttle (1972) die aandag daarop dat korrelasies tussen vraelysitems van dieselfde behoeftekategorie in die Portervraelys laag is en dat daar ' $n$ algemene neiging is dat vraelysitems van verskillende behoeftekategorieë met mekaar korreleer. Hulle toon ook aan dat die hoërorde behoefte-items onbetroubaar kan wees en bevraagteken die bruikbaarheid van hierdie vraelysitems om die verlangde behoeftekategorieë te meet. 
Die vereiste wat Dachler en Mobley (1973) aan hul vraelys gestel het, naamlik dat die taalgebruik in die vraelys van so " $n$ aard moes wees dat die proefpersone dit moes kon verstaan, kan ook vertolk word as "n behoefte aan 'n semanties getroue meetinstrument. In 'n poging om aan hierdie vereiste te kon voldoen, is vraelysitems in ' $n$ taalvlak weergegee wat gebaseer was op die taalgebruik wat proefpersone in onderhoude geopenbaar het.

Ten einde die houdbaarheid van die betoog ten gunste van die kontrolering van semantiese meerduidigheid empiries te bevestig, is die vraelys en bevindinge van Pottas aan noukeurige ondersoek onderwerp. Vir hierdie doel is die volgende hipotese geformuleer:

Pottas (1969) se vraelys weet nie wat dit veronderstel is om te meet nie, omdat die items wat daarin vervat is semanties verskil (in betekenis verskil) van daardie behoeftekategorieë (van Maslow se teorie) wat hulle veronderstel is om te omskryf.

\section{METODE}

\section{Strategie}

Die strategie van hierdie ondersoek was sodanig dat sekere veranderlikes (vraelysitems) en kriteria (behoeftekategorieë) gekwantifiseer moes word, sodat die betekenis van die vraelysitems met die van die behoeftekategorieë vergelyk kon word. Indien die twee beduidend van mekaar sou verskil sou dit beteken dat die vraelysitem(s) nie geldig is nie en dus nie meet wat dit veronderstel is om te meet nie, en omgekeerd (kyk hipotese).

\section{Meettegniek}

Die meetinstrument met behulp waarvan die vraelysitems en behoeftekategorieë gekwantifiseer is, is die semantiese differensiaal wat deur Osgood, Suci en Tannenbaum (1957) ontwikkel is en wat beskryf kan word as ' $n$ tegniek waarmee die sielkundige betekenis van konsepte waargeneem en gemeet kan word.

Wanneer daar byvoorbeeld aan iemand gevra word wat "selfvervulling" beteken, sal hy heel waarskynlik antwoord dat hy presies weet wat dit beteken, maar dat hy nie 'n definisie daarvan kan gee nie. Óf die individu kan poog om die konsep te omskryf en te verduidelik deur middel van ' $\mathrm{n}$ hele aantal woorde en sinsdele. In plaas daarvan om egter staat te maak op iemand se stortvloed van woorde en sinsdele, kan ' $n$ beter begrip van die individu se siening verkry word deur aan hom sekere vrae betreffende die konsep te vra. Daar kan byvoorbeeld aan hom gevra word of "selfvervulling" goed of sleg is, of dit aangenaam of onaangenaam is, 
of dit aktief of passief is, of dit ingebore of aangeleer is, of dit hard of sag is, ensovoorts. Die semantiese differensiaal (voortaan SD genoem) is ' $n$ instrument wat letterlik vir hierdie doel ontwerp is. Dit vra sekere vrae aan die individu om sodoende die konatiewe betekenis van konsepte te meet as punte in wat Osgood en sy medewerkers die "semantiese ruimte" noem.

\section{Konsepte}

Die vyf behoeftekategorieë en 13 vraelysitems van die Pottasvraelys is as konsepte oor 'n aantal bipolêre skale beoordeel, om hulle sodoende te kon kwantifiseer in terme van die betekenis wat proefpersone daaraan heg. Die fisiese uitleg van sodanige beoordeling het soos volg daaruit gesien:

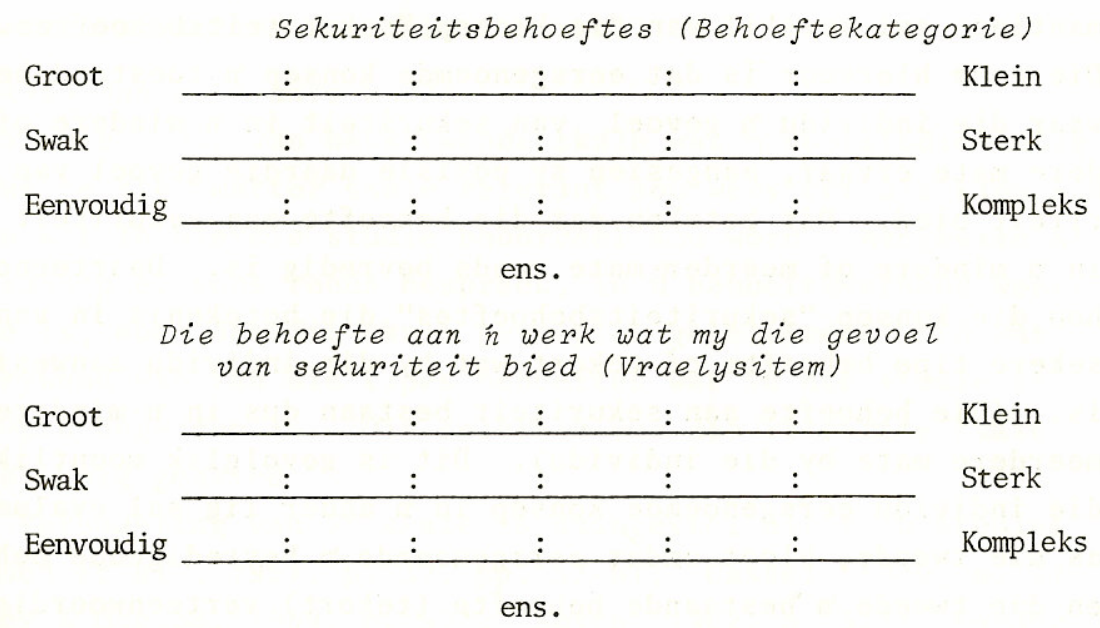

Volgens Osgood, et al., (1957) lê die kruks van konsepte wat uit meer as een woord bestaan daarin dat sodanige konsepte " $\mathrm{n}$ eenheidsgevoel by die proefpersoon moet opwek wanneer hy die konsep aanskou. Aangesien konsepte wat uit meer as een woord bestaan die nadeel inhou dat elke woord in wese ' $n$ aparte semantiese struktuur bevat, moet alles moontlik gedoen word om sodanige konsepte op so 'n wyse saam te stel dat hulle 'n enkele eenheidsbetekenis het.

Om die bogenoemde potensiële swakheid te minimaliseer, is besluit om konsepte in 'n "behoefteverband" weer te gee, sodat elke konsep "n sekere tipe behoefte verteenwoordig het vir die proefpersone wat dit moes beoordeel. Hierdie stap kan verduidelik word aan die hand van ' $n$ behoeftekategorie en vraelysitem uit die vraelys van Pottas.

Daar kan geredeneer word dat die konsep "die gevoel van sekuriteit wat my posisie my bied" uit die aard van die saak semanties sal verskil van die konsep "sekuriteitsbehoeftes." Die rede hiervoor is dat eersgenoemde konsep ' $n$ toestand beskryf waar die individu ' $n$ gevoel 
van sekuriteit in ' $n$ mindere of meerdere mate ervaar, aangesien sy posisie daardie gevoel van sekuriteit bied. Dit beteken dat die behoefte aan sekuriteit wel in " $n$ mindere of meerdere mate reeds bevredig is. Daarteenoor hou die konsep "sekuriteitsbehoeftes" die betekenis in van " $n$ sekere tipe behoefte of tekort wat by die individu aanwesig is. (Die behoefte aan sekuriteit bestaan dus in ' $n$ mindere of meerdere mate by die individu). Dit is gevolglik moontlik dat die individu eersgenoemde konsep in ' $n$ ander lig sal evalueer as die tweede, bloot omdat eersgenoemde ' $n$ bevredigende behoefte en die tweede ' $n$ bestaande behoefte (tekort) verteenwoordig. Die gevolg is dat foutvariansie hier kan meewerk tot verskille in betekenis.

Deur die vraelysitem in 'n behoefteverband te herskryf kan die foutvariansie geminimaliseer word. Die vraelysitem hierbo kan in hierdie opsig as volg herskryf word. "Die behoefte aan "n werk wat my die gevoel van sekuriteit bied." In so 'n geval word beide die behoeftekategorie en die vraelysitem in " $n$ behoefteverband aan die proefpersoon vir beoordeling voorgelê. Beide konsepte verteenwoordig dan 'n sekere tipe behoefte wat 'n individu ervaar.

Sou die twee konsepte nou nie beduidend van mekaar verskil nie, kan daar aanvaar word dat beide konsepte dieselfde tipe behoefte vir die individu beskryf, met ander woorde dat hulle semanties nie beduidend van mekaar verskil nie. Sou die twee konsepte egter wel beduidend van mekaar verskil, sal sodanige verskil toegeskryf kan word aan die feit dat die twee tipes behoeftes semanties van mekaar verskil.

\section{Seleksie van relevante skale}

Vir die keuse van beskrywende skale was 'n voorstudie nodig om vas te stel watter skale relevant sou wees tot die tipe konsepte wat in hierdie studie beoordeel sou word. Aangesien al die konsepte, soos reeds bespreek, in 'n behoefteverband weergegee is, moes daardie skale gevolglik geselekteer word wat beskrywend was van die tipes behoeftes wat in die studie as konsepte opgeneem is. Die seleksie van die relevante skale het as volg geskied:

' $n$ Versameling van 58 skale is saamgestel uit tien studies (Osgood et al., 1957, p. 37 , pp. 53-61; Cassel, 1970, p. 11; Snider \& Osgood, 1969, p. 587; Smith, 1962, p. 327.; Snyder \& Wiggins, 1970, p. 461; Brown, 1964, p. 365; Coyne \& Holzman, 1966; p. 667; Hunt, 1967, p. 243; Michon, 1960, p. 378; Warr \& Haycock, 1970, p. 333). Hierdie skale is toe in Afrikaans vertaal. 
Met "relevansie tot die konsep" as uitgangspunt is daardie skale wat volgens die skrywers se mening geen verband gehad het met die konsep "behoefte" nie, uitgeskakel. Die aantal skale is met hierdie stap verminder tot 34 .

Hierna is die nege bes beskrywende skale (drie elk vir die dimensies Evaluasie, Potensie en Aktiwiteit) geselekteer. Daar is geoordeel dat die betroubaarheid van resultate in hierdie stap verhoog kon word deur in plaas van slegs die konsep "behoefte", sekere van die behoeftes wat as konsepte in die studie opgeneem is, oor die 34 skale te laat beoordeel vir die seleksie van relevante skale wat uiteindelik in hierdie studie gebruik sou word. Vir hierdie doel is daar op die behoeftekategorieë fisiologiese- en selfverwesenlikingsbehoeftes besluit. Omdat hierdie twee behoeftekategorieë twee uiterstes op Maslow se behoeftehiërargie is, is geredeneer dat hulle tot die grootste eksperimentele variansie aanleiding sou gee indien hulle oor die betrokke skale beoordeel sou word.

Aan 'n ewekansige monster van 20 studente in die Bedryfsielkunde III-klas van 1977 aan die Universiteit van Stellenbosch is gevra om die konsepte "fisiologiese behoeftes" en "selfverwesenlikingsbehoeftes" oor die 34 skale te beoordeel. Die instruksies vir beoordeling was ooreenkomstig Osgood, et al. (1957, pp 82 - 84) se aanbevelings.

Met die seleksie van die nege mees relevante skale is die volgende aanname gemaak: Wanneer ' $n$ skaal irrelevant is tot die konsep wat beoordeel word, sal dit 'n neutrale beoordeling (d.w.s. ' $n$ beoordeling op die middelpunt van die betrokke skaal) by ' $n$ proefpersoon uitlok. Omgekeerd, 'n baie relevante skaal kan 'n uiterste beoordeling (d.w.s. 'n beoordeling op enige een van die twee eindpunte weerskante van die neutrale middelpunt van die betrokke skaal) by proefpersone uitlok. Die skaal met die grootste eenheidsafwyking vanaf die neutrale middelpunt sal gevolglik die mees relevante skaal wees.

Die afwykings per skaal vanaf die neutrale middelpunt van die 40 response (20 elk vir die twee konsepte) is gesommeer en hierna is die gemiddelde afwyking per skaal bereken. Ooreenkomstig die redenasie hierbo is die drie mees relevante skale tot die twee behoeftekategorieë wat beoordeel is (d.w.s. daardie skale met die grootste gemiddelde afwyking vanaf die neutrale middelpunt) vir die dimensies Evaluasie, Potensie en Aktiwiteit geselekteer. Hierdie skale was: 


\section{EVALUASIE}

$\begin{array}{ll}\text { belangrik } & \text { - onbelangrik } \\ \text { natuurlik } & \text { - onnatuurlik } \\ \text { nodig } & \text { - onnodig }\end{array}$

POTENSIE

$\begin{array}{ll}\text { groot } & \text { - klein } \\ \text { sterk } & \text { - swak } \\ \text { vasbeslote } & \text { - sorgeloos }\end{array}$

AKTIWITEIT

$\begin{array}{ll}\text { aktief } & \text { - passief } \\ \text { prikkelbaar } & \text { - kalm } \\ \text { veranderlik } & \text { - konstant }\end{array}$

\section{Proefpersone}

Om ' $n$ realistiese beskouing van die onderskeie behoeftekategorieë te verkry was proefpersone nodig wat ten volle vertroud was met die betekenis van die verskillende behoeftekategorieë. Om hierdie rede is daar besluit om Bedryfsielkundestudente in hul finale jaar aan die Universiteit van Stellenbosch as proefpersone te gebruik, aangesien die teorie van Maslow (waarop die Pottasvraelys gebaseer is) een van die motiveringsteorieë is wat breedvoerig in hierdie proefpersone se graadkursus behandel is.

Die universum van 94 studente in die Bedryfsielkunde III-klas van 1977 is in twee ewekansige groepe van 47 elk verdeel. 'n Vraelys, waarin onder andere die vyf behoeftekategorieë en 13 vraelysitems van die Pottasvraelys oor die nege SD-skale beoordeel moes word, is aan die een proefgroep gegee. (Die ander konsepte wat in hierdie vraelys opgeneem is, het gedien as basis vir die ontwikkeling van 'n semanties getroue Afrikaanse vraelys vir werknemers op hoë organisatoriese vlakke. Insgelyks het die ander proefgroep ' $n$ vraelys ontvang met konsepte wat gedien het as basis vir die ontwikkeling van 'n vraelys vir werknemers op lae organisatoriese vlakke. Geen bespreking word aan die ontwikkeling van die twee vraelyste gewy nie omdat dit buite die bestek van hierdie artikel val.)

Van die 47 vraelyste wat aan eersgenoemde proefgroep uitgehandig is, is 38 ingevulde vraelyste terugontvang. 


\section{Berekeningsmetode}

Die rekenkundige gemiddelde van die individuele beoordelings is bereken ten einde ' $\mathrm{n}$ matriks te verkry, met die konsepte en skale as die twee asse van die matriks. Vanuit hierdie matriks is die gemiddelde waarde van elk van Pottas se 13 vraelysitems en vyf behoeftekategorieë oor die nege SD-skale bereken. Hierna is die t-waardes bereken vir die verskille tussen die gemiddeldes van vraelysitems en daardie behoeftekategorieë wat hulle veronderstel was om te beskryf. In gevalle waar sodanige verskille beduidend was, is die hipotese aanvaar en in gevalle waar verskille nie beduidend was nie, is die hipotese verwerp.

\section{RESULTATE EN BESPREKING}

Tabel 1 dui die items van die vraelys van Pottas aan soos beoordeel deur die proefgroep en na elke vraelysitem, die t-waarde vir die verskil tussen die gemiddeldes van die betrokke vraelysitem en die behoeftekategorie wat dit veronderstel is om te beskryf.

\section{Sekuriteitsbehoeftes}

In Tabel 1 kan gesien word dat die vraelysitem wat sekuriteisbehoeftes behoort te meet, beduidend $(\mathrm{p}<, 01)$ van die behoeftekategorie verskil. Dit blyk dus dat hierdie vraelysitem nie geldig is nie en nie meet wat dit veronderstel is om te meet nie.

\section{Sosiale behoeftes}

Nie een van die twee vraelysitems wat hierdie behoeftekategorie meet verskil beduidend van laasgenoemde nie en beide vraelysitems is dus geldige beskrywings van die behoeftekategorie.

\section{Die behoefte aan erkenning}

Twee vraelysitems ( $5 \& 6$ ) in hierdie gedeelte van Pottas se vraelys verskil beduidend $(\mathrm{p}<, 01)$ van die behoeftekategorie, terwyl slegs een van die vraelysitems (4) 'n geldige beskrywing daarvan verteenwoordig. Die verskil tussen hierdie item en die behoeftekategorie neig egter na die $10 \%$-beduidenheidspeil. 


\section{Die behoefte aan selfstandigheid}

Twee van Pottas se vraelysitems ( 8 en 9) verteenwoordig geldige beskrywings van die selfstandigheidsbehoeftes, terwyl twee vraelysitems $(7$ en 10) beduidend $(p<, 05)$ van hierdie behoeftekategorie verskil.

\section{Die behoefte aan selfverwesenliking}

Die behoefte aan selfverwesenliking word deur twee geldige vraelysitems (11 en 12) beskryf, terwyl 'n derde vraelysitem $(13)$ beduidend $(\mathrm{p}<, 01)$ van hierdie behoeftekategorie verskil.

TABEL 1

t-WAARDES VIR DIE VERSKILLE TUSSEN GEMIDDELDES VAN VRAELYSITEMS EN BEHOEFTEKATEGORIË̈ VAN DIE VRAELYS VAN POTTAS

\begin{tabular}{|c|c|c|}
\hline & Konsep & t-Waarde \\
\hline & SEKURITEITSBEHOEFTES & \\
\hline 1 & $\begin{array}{l}\text { Die behoefte aan 'n werk wat my die gevoel van sekuriteit } \\
\text { bied. } \\
\text { SOSIALE BEHOEFTES }\end{array}$ & $5,6907 * *$ \\
\hline 2 & Die behoefte aan 'n werk waar ek hulp aan ander kan verleen. & 1,2679 \\
\hline 3 & $\begin{array}{l}\text { Die behoefte aan 'n werk waar ek goeie vriende kan maak. } \\
\text { DIE BEHOEFTE AAN ERKENNING }\end{array}$ & 1,0470 \\
\hline 4 & $\begin{array}{l}\text { Die behoefte aan 'n werk waar ek 'n gevoel van eiewaarde } \\
\text { verkry. }\end{array}$ & 1,7959 \\
\hline 5 & $\begin{array}{l}\text { Die behoefte aan 'n werk wat aan my prestige in die organ- } \\
\text { sasie bied. }\end{array}$ & $3,3909 * *$ \\
\hline 6 & $\begin{array}{l}\text { Die behoefte aan 'n werk wat aan my prestige buite die } \\
\text { organisasie bied. }\end{array}$ & $3,7274 * *$ \\
\hline & DIE BEHOEFTE AAN SELFSTANDIGHEID & \\
\hline 7 & $\begin{array}{l}\text { Die behoefte aan 'n werk waar gesag aan my posisie ver- } \\
\text { bonde is. }\end{array}$ & $2,9392 *$ \\
\hline 8 & $\begin{array}{l}\text { Die behoefte aan 'n werk wat my die geleentheid vir self- } \\
\text { standige denke en optrede bied. }\end{array}$ & 0,4035 \\
\hline
\end{tabular}


Tabel 1 (vervolg)

\begin{tabular}{|c|c|c|}
\hline & Konsep & t-Waarde \\
\hline 9 & $\begin{array}{l}\text { Die behoefte aan ' } \mathrm{n} \text { werk waar ek deel kan hê aan be- } \\
\text { sluite in verband met die doelstellings en oogmerke van } \\
\text { die organisasie. }\end{array}$ & 1,7620 \\
\hline 10 & $\begin{array}{l}\text { Die behoefte aan 'n werk wat my geleentheid bied vir deel } \\
\text { deelname aan die bepaling van metodes en prosedures in } \\
\text { die organisasie }\end{array}$ & $2,9371 *$ \\
\hline 11 & $\begin{array}{l}\text { Die behoefte aan 'n werk wat my geleentheid bied vir } \\
\text { persoonlike groei en ontwikkeling in my posisie. }\end{array}$ & 1,6020 \\
\hline 12 & $\begin{array}{l}\text { Die behoefte aan 'n werk waar ek die gevoel van self- } \\
\text { vervulling kan kry. }\end{array}$ & 1,0667 \\
\hline 13 & $\begin{array}{l}\text { Die behoefte aan 'n werk waar ek kan voel dat ek iets } \\
\text { nuttigs bereik in my posisie. }\end{array}$ & $3,7620 * *$ \\
\hline
\end{tabular}

Uit ' $n$ totaal van 13 items, bevat die vraelys van Pottas dus ses ongeldige items wat beduidend verskil van die onderskeie behoeftekategorieë wat hulle veronderstel is om te meet. Die resultate verleen steun aan die hipotese en toon onder meer die volgende aan:

- Die behoeftekategorie sekuriteitsbehoeftes word nie deur die Pottasvraelys gemeet nie, aangesien die vraelysitem wat veronderstel is om dit te meet, in betekenis beduidend daarvan verskil.

- Albei vraelysitems wat die behoeftekategorie sosiale behoeftes omskryf is geldig, met die gevolg dat meting van sosiale-behoeftes met behulp van die Pottasvraelys moontlik is.

- $\quad$ Die behoeftekategorieë erkenning en selfstandigheid sluit elke twee vraelysitems in wat ongeldig is omdat hulle beduidend verskil van die behoeftekategorieë wat hulle veronderstel is om te meet.

- $\quad$ Die behoeftekategorie selfverwesenliking bevat ' $n$ vraelysitem wat ongeldig is.

Volgens die verkreë resultate is die sosiale behoeftes dus die enigste behoeftekategorie wat wel deur Pottas se vraelys gemeet kan word. Alhoewel die behoeftekategorieë erkenning, selfstandigheid en selfverwesenliking geldige items insluit, bevat hulle egter ook ongeldige items. Die gevolg is dat resultate wat verkry is van individue se response op ongeldige items wat by die onderskeie behoeftekategorieë ingesluit is, tot foutiewe gevolgtrekkings kan lei.

Indien daar aanvaar kan word dat die Portervraelys (dus die Engelse weergawe van die Pottasvraelys) dieselfde semantiese tekortkominge het as die Pottasvraelys, is dit moontlik dat hierdie semantiese tekortkominge meer lig kan werp op 'n aantal tendense in die literatuur wat 
strydig is met die voorspellings van Maslow se teorie, veral ten opsigte van die twee behoeftekategorieë sekuriteit en erkenning, wat volgens die verkreë resultate nie voldoende deur die Pottasvraelys gemeet word nie. Die studies waaruit die onderstaande voorbeelde geneem is, het albei die vraelys van Porter gebruik om inligting mee in te samel:

Slocum, Topichak en Kuhn (1971) bevind in 'n kulturele vergelykingstudie dat beide Amerikaanse en Mexikaanse proefpersone sekuriteitsbehoeftes as die belangrikste behoeftearea beskou. Herrick (1973) rapporteer dat een proefgroep (Federale amptenare) sekuriteitsbehoeftes aandui as die behoeftekategorie waar die minste gebrek voorkom, terwyl die ander proefgroep (amptenare van die staat Kentucky) hierdie behoefte beskou as die een wat die minste bevredig is. Wat die behoeftekategorie erkenning betref, vind Herrick (1973) dat dit deur drie proefpersone as die mins belangrike en deur een groep as die tweede onbelangrikste behoefte beskou word. Hierdie bevindinge is strydig met die hiërargie soos voorgestel deur Maslow (1954).

Semantiese meerduidigheid, soos dit in die Pottasvraelys blootgelê is, bied 'n moontlike verklaring vir 'n bevinding deur Pottas (1969) self dat proefpersone sekuriteitsbehoeftes belangriker as die ander vier behoeftekategorieë ag (strydig met die teorie van Maslow). Hierdie tendens kan miskien nog verklaar word indien 'n land op 'n gegewe tydstip 'n buitengewone hoë werkloosheidskoers het. Die laat sestigerjare (waartydens die ondersoek deur Pottas gedoen is) was egter juis 'n tydperk wat as 'n ekonomiese bloeiperiode in Suid-Afrika geklassifiseer kan word.

\section{GEVOLGTREKKING}

Die ondersoek toon aan dat semantiese meerduidigheid in meetinstrumente gemanifesteer word en daartoe aanleiding gee dat meetinstrumente waarin hierdie bron van variansie nie gekontroleer is nie, ongeldig kan wees. Dit is voor die hand liggend dat sodanige meetinstrumente die navorser se resultate kan kontamineer en tot foutiewe gevolgtrekkings kan lei. In die verband bied semantiese meerduidigheid 'n waarskynlike verklaring vir uiteenlopende en kontroversiële navorsingsresultate in studies wat op 'n aantal motiveringsteorieë betrekking het.

In die lig van die resultate van hierdie studie, kan vraelyste wat nie vir semantiese meerduidigheid ondersoek is nie, as ongeldig beskou word. Die semantiese getrouheid van enige vraelys wat in toekomstige navorsingstudies gebruik word behoort gevolglik bevestig te word, aangesien vraelyste wat nie vir semantiese meerduidigheid gekontroleer is nie onder 
verdenking staan. 'n Metode is in hierdie ondersoek uiteengesit waarvolgens 'n ondersoek na semantiese meerduidigheid in vraelyste kan geskied en dit word vir dié doel aanbeveel.

Ten einde die probleem van semantiese meerduidigheid in vraelyste te oorbrug, het Zietsman (1978) twee semanties getroue meetinstrumente ontwikkel vir die meting van Maslow se motiveringsteorie; een vir werknemers op lae organisatoriese vlakke en een vir werknemers op hoë organisatoriese vlakke. Afgesien daarvan dat die twee vraelyste aangepas is by die taalvlak van die twee groepe, is hulle empiries gelyk aan mekaar en is albei vry van semantiese meerduidigheid.

\section{OPSOMMING}

Dit word aangevoer dat semantiese meerduidigheid, wat in meetinstrumente gemanifesteer word, die navorser se resultate kan kontamineer. Daar word voorts gesuggereer dat semantiese meerduidigheid 'n oorsaak kan wees van kontroversiële en uiteenlopende navorsingsresultate in studies wat betrekking het op 'n aantal motiveringsteorieë. 'n Oorsig van relevante literatuur dui daarop dat navorsers grootliks onbewus is van hierdie verskynsel en in hierdie ondersoek is geen gevalle gevind waar semantiese meerduidigheid in vraelyste gekontroleer is nie. Betekenismeting van die Pottasvraelys is in die ondersoek, deur middel van 'n semantiese differensiaal op 38 studente in die Bedryfsielkunde uitgevoer. Die resultate toon dat ses van die 13 vraelysitems semanties beduidend verskil van die behoeftekategorieë wat hulle veronderstel is om te meet. Die vermoede word sodoende bevestig dat semantiese meerduidigheid ' $n$ bron van variansie is wat as sulks gekontroleer behoort te word.

\section{VERWYSINGS}

Brown, W.P.: The title of paperback books. British Journal of Psychology, 1964, 55, 365-368.

Cassel, R.N.: Development of a semantic differential to assess the attitude of secondary school and college students. The Journal of Experimental Education, 1970, 39, 10-14.

Coyne, L. \& Holzman, P.S.: Three equivalent forms of a semantic differential inventory. Educational and Psychological Measurement, 1966, 26, 665-674.

Dachler, H.P. \& Mobley, W.H.: Construct validation of an instrumentality expectancy - task goal model of work motivation : Some theoretical boundary conditions. Journal of Applied Psychology, 1973, 58, 397-418.

Dunnette, M.D., Campbell, J.P. \& Hakel, M.: Factors contributing to job satisfaction and job dissatisfaction in six occupational groups. Organizational Behaviour and Human Performance, 1967, 2, 143-174.

Herrick, J.S.: Work motives of female executives. Public Personnel Management, 1973, 2, 380-387. 
Huizinga, G.: Maslow's need hierarchy in the work situation. Groningen : Wolters Noordhoff , 1970.

Hunt, R.A.: Self and other semantic concepts in relation to choice of a vocation. Journal of Applied Psychology, 1967, 51, 242-246.

Invancevich, J.M.: Perceived need satisfaction of domestic versus overseas managers. Journal of Applied Psychology, 1969, 53, 274-278.

Lawler, E.E. \& Suttle, J.L.: A causal correlation test of the need hierarchy concept. Organizational Behaviour and Human Performance, 1972, 7, 265-287.

Maslow, A.H.: Motivation and personality. New York: Harper \& Row, 1954.

Michon, J A. An application of Osgood's "semantic differential" technique. Acta Psychologica, 1960, 17, 377-391.

Mitchell, V.F.: Need satisfactions of military commanders and staff. Journal of Applied Psychology, 1970, 54, 282-287.

Nunnally, J.C.: Psychometric Theory. New York: McGraw-Hill, 1967.

Osgood, C.E., Suci, G.J. \& Tannenbaum, P.H.: The measurement of meaning. Urbana: University of Illinois Press, 1957.

Porter, L.W.: A study of perceived need satisfactions in bottom and middle management jobs. Journal of Applied Psychology. 1961, 45, 1-10.

Porter, L.W.: Job attitudes in management: I. Perceived deficiencies in need fulfilment as a function of job level. Journal of Applied Psychology, 1962, 46, 375-384.

Porter L.W.: Job attitudes in management: II. Perceived importance of needs as a function of job level. Journal of Applied Psychology. 1963(a), 47, 141-148.

Porter, L.W.: Job attitudes in management: III. Perceived deficiencies in need fulfilment as a function of line versus staff type of job. Journal of Applied Psychology, 1963(b), 47, 267-275.

Porter, L.W. \& Siegel, J. Relationships of tall and flat organization Structures to the satisfactions of foreign managers. Personnel Psychology, 1965, 18, 379-392.

Pottas, C.D.: ' $n$ Bedryfsielkundige ondersoek na die determinante van werksverhoudinge en werksmotivering. Ongepubliseerde Meestersverhandeling, Universiteit van Suid-Afrika, Pretoria, 1969.

Rhinehart, J.B., Barrell, R.P., de Wolfe, A.S., Griffin, J.E. \& Spaner, F.E.: Comparative study of need satisfactions in governmental and business hierarchies. Journal of Applied Psychology, 1969, 53, 230-235.

Slocum, J.W., Topichack, P.M., \& Kuhn, D.G.: A cross-cultural study of need satisfaction and need importance for operative employees. Personnel Psychology, 1971, 24, 435445.

Smith, P.A. A comparison of three sets of rotated factor analytic solutions of self-concept data. Journal of Abnormal and Social Psychology, 1962, 64, 326-333.

Snider, J.G. \& Osgood, C.E. Semantic differential technique. A sourcebook. Chicago: Aldine Publishing Company, 1969.

Snyder, F.W. \& Wiggins, Nancy: Affective meaning systems: A multivariate approach. Multivariate Behavioural Research, 1970, 5, 453-468.

Warr, P.B. \& Haycock, Valerie: Scales for a British personality differential. British Journal of Social and Clinical Psychology, 1970, 9, 328337.

Zietsman, S.H.: 'n Bedryfsielkundige ondersoek na semantiese meerduidigheid in motiveringsnavorsing. Ongepubliseerde Meestersverhandeling, Universiteit van Stellenbosch, Stellenbosch, 1978. 